LAWRENCE LIVERMORE N A T IO N A L LABORATORY
Chemical Kinetic Modeling of Dimethyl Carbonate in an Opposed-Flow Diffusion Flame

Pierre A. Glaude, William J. Pitz, Murray J.

Thomson

December 9, 2003

30th International Symposium on Combustion Chicago, IL, United States

July 25, 2004 through July 30, 2004 
This document was prepared as an account of work sponsored by an agency of the United States Government. Neither the United States Government nor the University of California nor any of their employees, makes any warranty, express or implied, or assumes any legal liability or responsibility for the accuracy, completeness, or usefulness of any information, apparatus, product, or process disclosed, or represents that its use would not infringe privately owned rights. Reference herein to any specific commercial product, process, or service by trade name, trademark, manufacturer, or otherwise, does not necessarily constitute or imply its endorsement, recommendation, or favoring by the United States Government or the University of California. The views and opinions of authors expressed herein do not necessarily state or reflect those of the United States Government or the University of California, and shall not be used for advertising or product endorsement purposes. 


\title{
Chemical Kinetic Modeling of Dimethyl Carbonate in an Opposed-Flow Diffusion Flame
}

\author{
Pierre A. Glaude \\ Departement de Chimie-Physique des Reactions, CNRS, France \\ William J. Pitz \\ Lawrence Livermore National Laboratory, U.S.A. \\ Murray J. Thomson \\ Department of Mechanical and Industrial Engineering, University of Toronto, Canada
}

Corresponding author:

William J. Pitz

Lawrence Livermore National Laboratory, L-091, P.O. Box 808

Livermore, CA 94551, U.S.A.

Phone: (925) 422-7730

Email: pitz@1lnl.gov

Name of Colloquium: Reaction Kinetics

Short Title: Dimethyl Carbonate Flame Modeling

\section{Word Count}

Total: 4418

Method

Text: 2804

References: $(29+2) * 2.3 * 7.6=542$

Tables: 1: 15 lines x $7.6+34$ word footnote 148

2: 12 lines $\times 7.6+30$ word footnote 121

3: 30 lines $\times 15.2+188$ word footnote $\quad 644$

4: 45 lines x $15.2+47$ word title 731

Figures: 1: $205 \mathrm{~mm}$ wide $\mathrm{x} 140 \mathrm{~mm}$ high +23 word caption 139

2: $208 \mathrm{~mm}$ wide $\mathrm{x} 142 \mathrm{~mm}$ high +21 word caption $\quad 137$

3: $208 \mathrm{~mm}$ wide $\mathrm{x} 138 \mathrm{~mm}$ high +19 word caption $\quad 132$

4: $168 \mathrm{~mm}$ wide $\mathrm{x} 122 \mathrm{~mm}$ high +31 word caption 153

Equation: $13 * 7.6=99$

Total paper $=5651$ words

Abstract $=295$ words

Keywords: Dimethyl Carbonate, Oxygenated Fuel, Opposed Flow Flame, Chemical Kinetic Modeling, Flame Structure 


\begin{abstract}
Dimethyl carbonate (DMC) has been of interest as an oxygenate additive to diesel fuel because of its high oxygen content. In this study, a chemical kinetic mechanism for DMC was developed for the first time and used to understand its combustion under conditions in an opposed flow diffusion flame. Computed results were compared to experimental results from an opposed flow diffusion flame. It was found that the decomposition rate $\mathrm{DMC} \Rightarrow \mathrm{H}_{3} \mathrm{COC}(=\mathrm{O}) \mathrm{O} .+\mathrm{CH}_{3}$ in the flame was much slower than originally thought because resonance stabilization in the $\mathrm{H}_{3} \mathrm{COC}(=\mathrm{O}) \mathrm{O}$. radical was less than expected. Also, a new molecular elimination path for DMC is proposed and its rate calculated by quantum chemical methods. In the simulations of DMC in the flame, it was determined that much of the oxygen in dimethyl carbonate goes directly to $\mathrm{CO}_{2}$. This characteristic indicates that DMC would not be an effective oxygenate additive for reducing soot emissions from diesel engines. In an ideal oxygenate additive for diesel fuel, each oxygen atom stays bonded to one carbon atom in the products thereby preventing the formation of carbon-carbon bonds that can lead to soot. When $\mathrm{CO}_{2}$ is formed directly, two oxygen atoms are bonded to one carbon atom thereby wasting one oxygen atom in the oxygenate additive. To determine how much $\mathrm{CO}_{2}$ is formed directly, the branching ratio of the key reaction, $\mathrm{CH}_{3} \mathrm{OC} .=\mathrm{O}$ going to the products $\mathrm{CH}_{3}+\mathrm{CO}_{2}$ or $\mathrm{CH}_{3} \mathrm{O}+\mathrm{CO}$ was determined by ab initio methods. The Afactors of the rate constant of this reaction were found to be about 20 times higher than previous estimates. The new reaction rate constants obtained can be used as reaction rate rules for all oxygenates that contain the ester moiety including biodiesel.
\end{abstract}




\section{Introduction}

In the United States, standards for soot emissions from diesel engines are becoming more stringent. In 2007, US standards will require a 90\% reduction in soot emissions from current levels for heavy duty diesel engines [1]. The use of oxygenated fuels has the potential to reduce soot from diesel engines. Also, many oxygenated fuels are bio-derived and renewable fuels so that their use, rather than that of fossil fuels, helps to reduce $\mathrm{CO}_{2}$ emissions. Oxygenated fuels act by preventing some of the carbon in the fuel from forming soot. In an optimal oxygenate fuel, each $\mathrm{O}$ atom in the fuel will pair up with one carbon atom to form $\mathrm{CO}$ thus preventing a carbon atom from combining with another carbon to eventually form soot.

Oxygenates also increase the amount of oxygenated species, like $\mathrm{OH}$ radicals, in the fuel rich regions of the diesel jet so that unsaturated hydrocarbon species are oxidized rather than participating in soot growth reactions. Dimethyl carbonate $\left(\left(\mathrm{CH}_{3} \mathrm{O}\right)_{2} \mathrm{C}=\mathrm{O}\right)$ is an attractive oxygenated fuel because of its very high weight percent of oxygen. It offers the possibility of the adding a small amount of oxygenate to a conventional diesel fuel and obtaining a relatively large amount of oxygen by weight in the blended fuel. Diesel engines studies have shown that dimethyl carbonate addition to the fuel can significantly reduce smoke emissions [2]. However, the many simultaneous processes in an engine make it difficult to determine the mechanism responsible for this decrease.

Dimethyl carbonate (DMC) also has key chemical kinetic features that make it of interest in the investigation of oxygenate chemistry. DMC leads to the formation of the methoxy formyl radical $\left(\mathrm{CH}_{3} \mathrm{OC} .=\mathrm{O}\right)$, a key moiety in oxygenate chemistry. The generalized moiety in oxygenated fuels is $\mathrm{ROC} .=\mathrm{O}$ where $\mathrm{R}$ is a hydrocarbon chain. This structure can lead to $\mathrm{CO}$ or $\mathrm{CO}_{2}$ :

ROC. $=\mathrm{O} \Rightarrow>\mathrm{R} .+\mathrm{CO}_{2}$ 
ROC. $=\mathrm{O}=>\mathrm{RO} .+\mathrm{CO}$

Reaction A leads to $\mathrm{CO}_{2}$, which wastes the oxygen in the oxygenated fuel because two $\mathrm{O}$ atoms are attached to one carbon atom. Reaction B is the desired path for an ideal oxygenated fuel because each oxygen atom pairs up with one carbon atom (one carbon atom in $\mathrm{CO}$ and one carbon atom in RO.). The ROC. $=\mathrm{O}$ moiety with its key branching ratio appears in the chemistry of practical oxygenated fuels like dibutyl maleate [3] that has been identified as a very attractive fuel for diesel engines [4]. Indeed, this moiety appears in the chemistry of all biodiesel fuels derived from plants, because of their methyl ester molecular structure. It was to identify this key branching ratio in a relatively simple chemical system that this study was initially undertaken.

\section{Approach}

A detailed chemical kinetic model for DMC was developed. The thermodynamic parameters for DMC and its associated species were estimated using quantum chemistry methods and group additivity [5,6]. The enthalpies of formation and the entropies at 298K for the relevant species are given in Table 1. For most species, the enthalpy of formation was computed using CBS-Q methods with geometries optimized at the B3LYP/6-31G(d,p) level, in accordance with the methodology proposed by Bozzelli [8]. Zero point vibrational energy and thermal corrections were obtained with scaled frequencies as recommended by Scott and Radom [9] (0.9806 for B3LYP/6-31G(d,p)). The calculations were performed using the Gaussian98 computer program [10]. Corrections using isodesmic reactions were made. The computed enthalpies of formation are given in Table 1. The CBSQ enthalpies of formation compare very closely to values computed using G2 with isodesmic corrections [7]. Bond dissociation energies were computed from the enthalpies of formation (Table 2). The $\mathrm{C}-\mathrm{H}$ bond strength in $\mathrm{DMC}$ is about the same as a primary $\mathrm{C}-\mathrm{H}(101 \mathrm{kcal} / \mathrm{mole},[11])$, although it had been expected it would be weakened due to 
the presence of the $\mathrm{O}$ atom, as is the case in dimethyl ether $(\mathrm{C}-\mathrm{H}$ bond strength of $97.0 \mathrm{kcal} / \mathrm{mole}$ [7]). The stronger $\mathrm{C}-\mathrm{H}$ bond strength in DMC relative to DME is consistent with the low reaction rate of DMC with $\mathrm{OH}$ compared to DME. [12].

The reaction rate constants for reactions involving DMC were obtained by estimates based on reaction rate constants of other oxygenated fuels like dimethyl ether, formic acid and methyl butanoate [13,14]. Quantum mechanical calculations were performed to obtain a more accurate estimate of the key branching ratio for Reaction $\mathrm{A}$ and $\mathrm{B}$ for the case where $\mathrm{R}$ is $\mathrm{CH}_{3}$. The transition states for Reaction A and B were computed using CBS-Q methods. The rate constants were computed from simple transition state theory. The barrier was determined from the average difference between the energy calculated for the transition state and the energies of both reactant and products, again following the methodology of Bozzelli [15]. The internal rotors of the $\mathrm{CH}_{3} \mathrm{OC} .=\mathrm{O}$ species and transition states were computed to obtain pre-exponential factors for reaction paths $\mathrm{A}$ and $\mathrm{B}$ that were as accurate as possible. The torsional potential energy of the rotors was computed at $30^{\circ}$ intervals at the B3LYP/6-31G(d,p) level. The contributions of the hinder rotors to the entropy and specific heat as a function of temperature were determined by integration of the calculated torsional potential energy curves using the ROTATOR program $[16,17]$. The DMC reactions and their associated rate constants are given in Table 3. The DMC reactions were added to a previously developed chemical kinetic mechanism for dimethoxy methane and dimethyl ether. [14,23]. The entire reaction mechanism can be obtained electronically from the authors.

The barrier heights for $\mathrm{CH}_{3} \mathrm{OC} .=\mathrm{O}$ reacting to $\mathrm{CH}_{3}+\mathrm{CO}_{2}$ (Reaction -25$)$ and $\mathrm{CH}_{3} \mathrm{O}+\mathrm{CO}$ (Reaction -26) have been computed by Good and Francisco [7]. Using a G2 level of theory, they computed $14.7 \mathrm{kcal} / \mathrm{mole}$ to $\mathrm{CO}_{2}$ and $21.8 \mathrm{kcal} / \mathrm{mole}$ to $\mathrm{CO}$. Our barrier height showed close 
agreement: the same barrier to $\mathrm{CO}_{2}$ and $22.7 \mathrm{kcal} / \mathrm{mole}$ to $\mathrm{CO}$. They did not compute the preexponential factors for these reactions.

The OPPDIF code [24], a 1-dimensional steady-state flame code, was used to model the opposed flow diffusion flame structure. The transport parameters for DMC were obtained using the critical temperature and pressure from the NIST WebBook [25] and the Tee, Gotoh, Stewart correlation as stated in [26]. The transport parameters for other DMC species for which critical properties were not available were estimated as being the same as other species similar in size and structure. The multicomponent diffusion option in OPPDIF was used for species transport, and thermal diffusion was included in the calculation of diffusion velocities. The energy equation was solved and the temperature profile computed. The number of grid points was increased until the computed species and concentration profiles were grid independent.

\section{Experimental}

Experimental measurements were conducted at atmospheric pressure using an opposed flow diffusion flame burner. The burner consisted of two opposing identical stainless steel outlets that direct the fuel stream and oxidizer stream into a stagnation point flow. Each inlet port consists of two co-axial cylinders of diameter $25 \mathrm{~mm}$ and $39 \mathrm{~mm}$ respectively, forming an inner tube for the main flow (fuel or oxidizer), and an annulus for the nitrogen co-flow. The two cylinders are spaced $20 \mathrm{~mm}$ apart. Both fuel and oxidizer streams have the same inlet velocity of $10 \mathrm{~cm} / \mathrm{sec}$.

Details of the experimental conditions are given elsewhere [27]. The oxidizer stream containing $39 \% \mathrm{O}_{2}$ and $61 \% \mathrm{~N}_{2}$ was sent through the top burner port; 8\% dimethyl carbonate (DMC) and $92 \% \mathrm{~N}_{2}$ was sent through the bottom. The composition and flow rate of the oxidizer and fuel stream have been chosen in such a manner that, (1) approx. equal momentum is achieved at the 
fuel and the oxidizer port exits; (2) at flame plane, the $\mathrm{N}_{2} / \mathrm{O}_{2}$ ratio is near to that for air. The DMC was pumped using a peristaltic pump and passed through a loop kept in a hot water bath, where it was vaporized and mixed with the fuel mixture before being routed to the burner. The fuel flow line and burner port was heated to $45^{\circ} \mathrm{C}$ to avoid any condensation.

Sampling was accomplished by continuously withdrawing gases from within the flame using a quartz micro-probe with $200-220 \mu \mathrm{m}$ outer diameter at the tip and an orifice diameter of $120-150$ $\mu \mathrm{m}$; low visible disturbance to the flame was observed. The probe was kept stationary and the burner was moved in order to measure the axial concentration profile of the flame. An oil-free dual-stage heated-head vacuum pump drew the samples from the microprobe along heated Teflon tubing, through a filter and pushed the sample through the sample loop of a Varian 3800 series GC/FID. A vacuum pressure of 710-730 $\mathrm{mm} \mathrm{Hg}$, measured just downstream of the microprobe, promoted rapid cooling in the probe tip. Simultaneous reduction of pressure and the destruction of free radicals on the probe walls were sufficient to stop the reactions and ensured accurate data on flame composition. Microprobes of various diameters were tested to determine the appropriate size. All the runs were conducted in low or no sooting conditions to avoid any clogging of the microprobe. The GC system measured $\mathrm{C}_{1}-\mathrm{C}_{6}$ species using an HP-AL/S PLOT Column. DB-Wax capillary column was used to analyze the oxygenated species in the flame. Measurement of formaldehyde has been performed using HPLC technique. The gas samples were allowed to pass through LpDNPH cartridge where the carbonyls were trapped. The samples were then elutriated using acetonitrile and the liquid sample was analyzed with HPLC using a variable wavelength UV detector. The $\mathrm{CO} / \mathrm{CO}_{2}$ concentrations were measured using a separate NDIR analyzer. Temperature measurements were taken using a $250-\mu \mathrm{m}$ diameter R-type thermocouple. 
The measured temperatures were corrected to account for radiation losses from the thermocouple [28].

\section{Results}

The comparison between the results of the model and of the experiments is given in Fig.

1-3. The agreement between the experiments and model is shown in Fig. 1 for the major species. The temperature profile, the shape of the fuel curve, the position of $\mathrm{CO}$ and $\mathrm{CO}_{2}$ peaks, and the CO peak height are in reasonable agreement. This gives confidence that results from model can be used to identify the key chemistry for DMC. However, the model misses some of the early consumption of the fuel and its accompanying production of $\mathrm{CO}$. The predicted $\mathrm{CO}_{2}$ peak height is about 30\% higher than the experimental peak. A calculation was performed to assess the sensitivity of the $\mathrm{CO}$ and $\mathrm{CO}_{2}$ peak concentrations to the barrier heights for Reactions -25 and 26 which were increased by $1 \mathrm{kcal} / \mathrm{mole}$ and decreased by $1 \mathrm{kcal} / \mathrm{mole}$, respectively. These amounts are within the uncertainty of the computed barrier heights. The $\mathrm{CO}_{2}$ peak was unchanged and the $\mathrm{CO}$ peak concentration showed a $10 \%$ increase. Lowering the barrier to $\mathrm{CO}$ by $1 \mathrm{kcal} / \mathrm{mole}$ would be consistent with the barrier height reported by Good and Francisco [7]. The comparison of the minor species is given in Fig. 2. The species concentration profiles are in reasonable agreement, but the model predicts a higher peak for ethene than ethane. The predicted methane peak is also high. Modeling calculations showed that the heights of the ethene, ethane methane and acetylene peaks are very sensitive to the peak flame temperature. If the peak flame temperature is lowered slightly, more methyl recombination occurs in the flame to form ethane.

The peak $\mathrm{C}_{2} \mathrm{H}_{4}, \mathrm{C}_{2} \mathrm{H}_{6}, \mathrm{CH}_{4}, \mathrm{C}_{2} \mathrm{H}_{2}$ levels change by $70,-31,280,173 \mathrm{ppm}$, respectively, for a 
$100 \mathrm{~K}$ increase in peak flame temperature. On a percentage basis, acetylene is most sensitive to temperature.

The comparison for formaldehyde concentration profiles is given in Fig. 3. The agreement is reasonable given that formaldehyde is difficult to measure. The profiles show somewhat different shapes, but some of this difference may be due to probe averaging effects. The quartz microprobe draws gases from 2-3 orifice diameters from its tip [29], which results in a reduction of gradients and a smoothing of the composition profiles. This may be some of the reason why the predicted concentration profiles show higher gradients than the measured profiles.

\section{Discussion}

The key reaction paths for DMC are given in Fig. 4. Reaction 6 is the decomposition of DMC to methyl radicals. In preliminary calculations, it was found to consume about $75 \%$ of the DMC and to give too high concentrations of the minor hydrocarbon species shown in Fig. 2. Quantum mechanical calculations showed that the $\mathrm{CH}_{3}-\mathrm{O}$ bond in DMC $(89.6 \mathrm{kcal} / \mathrm{mole})$ is much stronger than initially thought based on initial group additivity estimates $(59.1 \mathrm{kcal} / \mathrm{mole})$ and the resonant stabilization of the $\mathrm{CH}_{3} \mathrm{OC}(=\mathrm{O}) \mathrm{O}$. radical was much lower than expected. When the bond strength was increased to the $a b$ initio value, this decomposition path no longer played a role in DMC consumption in the opposed-flow flame.

The main consumption path of DMC is reaction with H-atoms (Reactions 7-15). The DMC radical is produced which rapidly decomposes to formaldehyde and $\mathrm{CH}_{3} \mathrm{OC} .=\mathrm{O}$. The methoxy formyl radical can decompose by two paths, reactions 25 and 26. Our new quantum mechanical estimates show that about $78 \%$ of this radical leads to $\mathrm{CO}_{2}$ and $22 \%$ leads to $\mathrm{CO}$. Also, the new results show that the pre-exponential factor for the decomposition for both channels is about 10 
times larger than the original estimate. These new rate constants can be used as a reaction rate rule in describing these key reaction steps for all oxygenates with an ester structure that produces the ROC. $=\mathrm{O}$ moiety. All biodiesel derived from vegetative sources have this ester structure. Since these reaction steps are endothermic, it is preferable to specify the reverse rate as a reaction rate rule so that the activation energy does not directly contain the enthalpy of reaction. The reaction rate rules for reaction 25 and 26 are:

$\mathrm{k}_{25}=4.76 \times 10^{7} \mathrm{~T}^{1.54} \exp (-34710 . \mathrm{cal} / \mathrm{RT})$

$\mathrm{k}_{26}=1.55 \times 10^{6} \mathrm{~T}^{2.02} \exp (-5734 \cdot \mathrm{cal} / \mathrm{RT})$.

They are also given in Table 3 for the case of $\mathrm{CH}_{3} \mathrm{OC}=\mathrm{O}$.

These new reaction rate rules affect the predicted amount of direct $\mathrm{CO}_{2}$ production for dimethyl butanoate, an oxygenate that has been considered attractive for use in diesel engines [4]. The new reaction rate rules change the branching ratio of the $\mathrm{ROC} .=\mathrm{O}$ radical (where $\mathrm{R}$ is $\mathrm{n}$-butyl) from about $40 \%$ of this species going to $\mathrm{CO}_{2}$ at $1000 \mathrm{~K}$ to $90 \%$ going to $\mathrm{CO}_{2}$. This means that dibutyl maleate is even less attractive as an oxygenate than is reported in previous chemical kinetic estimates [3] because each $\mathrm{CO}_{2}$ formed directly represents ineffective use of one $\mathrm{O}$ atom in the parent oxygenate molecule.

Another significant finding in the present study is that a new molecular elimination path for DMC was discovered which had not previously been reported in the literature,

$$
\mathrm{DMC}=>\mathrm{CH}_{3} \mathrm{OCH}_{3}+\mathrm{CO}_{2}
$$

The activation energy for the reaction was determined by CBS-Q plus corrections with isodesmic reactions. The computed activation energy of $69.8 \mathrm{kcal} / \mathrm{mole}$ was higher than expected. Most 4centered molecular elimination reactions of this type have an activation energy of about 60 $\mathrm{kcal} / \mathrm{mole}$ (e.g. $58.7 \mathrm{kcal} / \mathrm{mole}$ for methyl t-butyl ether 4-centered elimination [18]). The pre- 
exponential factor in Table 3 was based on that of MTBE, divided by 9 due to reaction degeneracy in MTBE.

An analysis has been made of the sensitivity of the observed species concentrations to the reaction rate constants. Table 4 presents the reactions with the highest first order sensitivity coefficients for each observed species. A positive sensitivity indicates that increasing the reaction rate increases the target species concentration and a negative sensitivity indicates the opposite. Most of the species in Table 4 are highly sensitive to the reaction rate constants of reactions 25 and 26, discussed above. The results show that $\mathrm{CO}$ is equally and oppositely sensitive to the rate constants of reaction 25 and 26 . These reactions are also the most sensitive reactions affecting the fuel concentration. Reaction 25 gives a $\mathrm{CH}_{3}$ radical that is unreactive with the fuel and shows a positive sensitivity. However, Reaction 26 produces $\mathrm{CH}_{3} \mathrm{O}$ which decomposes to $\mathrm{CH}_{2} \mathrm{O}$ and a $\mathrm{H}$ atom which is highly reactive with the fuel and gives a negative sensitivity.

\section{Conclusions}

A chemical kinetic mechanism for DMC was developed for the first time. Results from the chemical kinetic mechanism were compared to recent measurements of DMC in an opposed-flow non-premixed flame. Many of the predicted composition profiles are in reasonable agreement with the measured profiles. The rate constant of the decomposition of a key intermediate was determined which has an impact on the predicted effectiveness of DMC as an oxygenate in reducing soot from diesel engine combustion. This rate constant also has an impact on the predicted effectiveness of all oxygenates that contain an ester moiety including biodiesel fuels. 


\section{Acknowledgements}

The authors wish to thank Dr. Henry Curran for an advance copy of his DMM mechanism, Dr.

Charles Westbrook for valuable technical discussions and Professor Joseph Bozzelli for help with the hindered rotor calculations. This work was supported by the U.S. Department of Energy, Office of Freedom CAR and Vehicle Technologies and was performed under the auspices of the U.S. Department of Energy by the Lawrence Livermore National Laboratory under contract No. W-7405-ENG-48. The authors thank program managers Stephen Goguen and Gurpreet Singh for their support of this work. Murray Thomson was supported by the Auto21 National Centre of Excellence.

References

1. Federal Register 66, No. 12 (2001) 5005. (http://www.epa.gov/fedrgstr/EPAAIR/2001/January/Day-18/a01a.pdf).

2. Miyamoto, N., Ogawa, H., and Arima, T., SAE Paper \#962115 (1996).

3. Mueller, C. J., Pitz, W. J., Pickett, L. M., Martin, G. C., Siebers, D. L., and Westbrook, C. K., Society of Automotive Engineers, SAE \#2003-01-1791, 2003.

4. Gonzalez, M.A., Piel, W., Asmus, T., Clark, W., Garbak, J., Liney, E., Natarajan, M., Naegeli, D.W., Yost, D., Frame, E., and Wallace, J.P., SAE Trans., 110 (2001), SAE Paper \#2001-01-3632.

5. Ritter, E.R., and Bozzelli, J.W., Int. J. Chem. Kinet. 23 (1991) 767-778.

6. Lay, T., Bozzelli, J.W., Dean, A.M., and Ritter, E.R., J. Phys. Chem. 99 (1995) 14514.

7. Good, D. A. and Francisco, J. S., J. Phys. Chem. A. 104 (2000) 1171-1185. 
8. Zhu, L., Chen, C.J., and Bozzelli, J.W., J. Phys. Chem. A 104 (2000) 9197.

9. Scott, A.P., and Radom, L., J. Phys. Chem. 100 (1996) 16502.

10. Gaussian 98, Revision A.7, Gaussian, Inc., Pittsburgh PA, 1998. http://www.gaussian.com/

11. P. W. Seakins, M. J. Pilling, J. T. Niiranen, D. Gutman, and L. N. Krasnoperov, J. Phys. Chem. 96 (1992) 9847-9855.

12. M. Bide, T. E. Mogelberg, J. Sehested, O. J. Nielson, T. J. Wallingon, M. D. Hurly, S. M. Japar, M. Dill, V.L. Orkin, T.J. Buckley, R. E. Huie, and M. J. Kurylo, J. Phys. Chem. 101 (1997) 3514-3525.

13. Fisher, E.M., Pitz, W.J., Curran, H.J., and Westbrook, C.K., Proc. Comb. Inst., 28 (2000) 1579-1586.

14. Fischer, S.L., Dryer, F.L., and Curran, H.J., Int. J. Chem. Kinetics, 32 (2000) 713-740.

15. C.-C. Chen and J. W. Bozzelli, J. Phys. Chem. A 22 (2003) 4531-4546.

16. Lay, T. H., Krasnoperov, L. N., Venanzi, C. A., Bozzelli, J. W., and Shokhirev, N. V., J. Phys. Chem. 100 (1996) 8240.

17. Shokhirev, N.V., and Krasnoperov, L.N., Program ROTATOR, (http://www.chem.arizona.edu/faculty/walk/nikolai).

18. Chen, C.-J. and Bozzelli, J. W., Chemical and Physical Processes in Combustion, Proceedings of Eastern Section Combustion Institute Fall Technical Meeting, 2, , 1999, pp. 37-40.

19. Curran, H. J., Gaffuri, P., Pitz, W. J., and Westbrook, C. K., Combustion and Flame, 129 (2002) 253-280. 
20. Curran, H. J., Gaffuri, P., Pitz, W. J., and Westbrook, C. K., Combust. Flame 114 (1998) $149-177$.

21. Held, T., and Dryer, F. J., Int. J. Chem. Kinet. 30 (1998) 805-830.

22. Hippler, H., Striebel, F. and Viskolcz, B., Phys. Chem. Chem. Phys. 3 (2001) 2450-2458.

23. H.J. Curran, Private communication, 2002.

24. The OPPDIF Application is part of the CHEMKIN Collection. Release 3.7.1, Reaction Design, Inc., San Diego, CA (2003), http://www.reactiondesign.com/.

25. Frenkel, M., in P.J. Linstrom and W.G. Mallard (Eds.), NIST Chemistry WebBook, NIST Standard Reference Database Number 69, March 2003, National Institute of Standards and Technology, Gaithersburg MD, 20899 (http://webbook.nist.gov).

26. Wang, H, and Frenklach, M., Comb. Flame 96 (1994) 163-170.

27. Sinha, A. and Thomson, M.J., submitted to Combustion and Flame, 2003.

28. Fristrom and Westenberg, Flame Structure. McGraw Hill Series, 1963.

29. Fristrom, R.M., Fire Research Abstracts and Reviews 16 (1974) 109. 
Table 1: Thermodynamic Data for DMC species

\begin{tabular}{|c|c|c|c|}
\hline \multirow[t]{3}{*}{ Species } & $\mathrm{H}_{\mathrm{f} 298 \mathrm{~K}}^{\circ}$ & $S(298 K)$ & $\mathrm{H}_{\mathrm{f} 298 \mathrm{~K}}$ \\
\hline & (This & Study) & G2[7] \\
\hline & $\mathrm{kcal} / \mathrm{mole}$ & $\mathrm{cal} / \mathrm{mole}-\mathrm{K}$ & $\mathrm{kcal} / \mathrm{mole}$ \\
\hline $\operatorname{coc}(=0) O C$ & $-136.06^{a}$ & 84.03 & - \\
\hline $\operatorname{coc}(=0) O C$. & $-88.10^{a}$ & 86.18 & - \\
\hline $\operatorname{coc}(=0) O$. & $-81.29^{a}$ & 70.85 & - \\
\hline $\mathrm{CJOC}(=\mathrm{O}) \mathrm{OH}$ & -93.64 & 74.05 & - \\
\hline $\mathrm{CH}_{3} \mathrm{OCHO}$ & $-86.01^{a}$ & 71.34 & -85.7 \\
\hline $\mathrm{CH}_{3} \mathrm{OC} . \mathrm{O}$ & $-37.77^{a}$ & 72.38 & -37.5 \\
\hline $\mathrm{CH}_{2} \cdot \mathrm{OCHO}$ & -36.19 & 73.68 & -36.5 \\
\hline $\mathrm{CH}_{3} \mathrm{OC}(=\mathrm{O}) \mathrm{OH}$ & $-140.93^{a}$ & 71.92 & - \\
\hline
\end{tabular}

Note: "=" means double bond, carbons are assumed to be saturated except where there is a radical site denoted by “.”.

${ }^{a}$ The enthalpy is calculated from CBS-Q calculation as described in the text. 
Table 2: Bond Dissociation Energies for DMC species

$\begin{array}{cr}\text { Species } & -\mathrm{H}(298 \mathrm{~K}) \\ & \mathrm{kcal} / \mathrm{mole} \\ & 111.7 \\ \operatorname{COC}(=\mathrm{O}) \mathrm{O}-\mathrm{H} & 89.6 \\ \operatorname{COC}(=\mathrm{O}) \mathrm{O}-\mathrm{C} & 101.1 \\ \operatorname{COC}(=\mathrm{O}) \mathrm{OC}-\mathrm{H} & 102.4 \\ \operatorname{COC}(=\mathrm{O})-\mathrm{OC} & 100.3 \\ \operatorname{COC}(=\mathrm{O})-\mathrm{H} & 112.6 \\ \operatorname{COC}(=\mathrm{O})-\mathrm{OH} & \end{array}$

Note: “-“ is used to indicated bond being broken. "=” means double bond, carbons are assumed to be saturated. Enthalpy is calculated from CBS-Q calculation as described in the text. 
Table 3: Reaction Rate Constants for DMC reactions (cal-mole-sec units)

Reaction

$1 \mathrm{COC}^{*} \mathrm{OOC}=\mathrm{CH}_{3} \mathrm{OCH}_{3}+\mathrm{CO}_{2}$

$2 \mathrm{COC}^{*} \mathrm{OOC}+\mathrm{O}_{2}=\mathrm{COC}^{*} \mathrm{OOC} .+\mathrm{HO}_{2}$

$4 \mathrm{COC}^{*} \mathrm{OOC} .+\mathrm{H}=\mathrm{COC}^{*} \mathrm{OOC}$

$5 \mathrm{CH}_{3} \mathrm{OCO}+\mathrm{CH}_{3} \mathrm{O}=\mathrm{COC}^{*} \mathrm{OOC}$

$6 \mathrm{COC}^{*} \mathrm{OO} .+\mathrm{CH}_{3}=\mathrm{COC}^{*} \mathrm{OOC}$

$7 \quad \mathrm{COC}^{*} \mathrm{OOC}+\mathrm{OH}=\mathrm{COC}^{*} \mathrm{OOC} .+\mathrm{H}_{2} \mathrm{O}$

$8 \mathrm{COC}^{*} \mathrm{OOC}+\mathrm{H}=\mathrm{COC}^{*} \mathrm{OOC} .+\mathrm{H}_{2}$

$9 \mathrm{COC}^{\star} \mathrm{OOC}+\mathrm{CH}_{3}=\mathrm{COC}^{*} \mathrm{OOC} .+\mathrm{CH}_{4}$

$10 \mathrm{COC}^{*} \mathrm{OOC}+\mathrm{O}=\mathrm{COC}^{*} \mathrm{OOC} .+\mathrm{OH}$

$11 \mathrm{COC}^{*} \mathrm{OOC}+\mathrm{HO}_{2}=\mathrm{COC}^{*} \mathrm{OOC} .+\mathrm{H}_{2} \mathrm{O}_{2}$

$12 \mathrm{COC}^{*} \mathrm{OOC}+\mathrm{CH}_{3} \mathrm{O}_{2}=\mathrm{COC}^{*} \mathrm{OOC}$. $+\mathrm{CH}_{3} \mathrm{O}_{2} \mathrm{H}$

$13 \mathrm{COC}^{*} \mathrm{OOC}+\mathrm{CH}_{3} \mathrm{O}=\mathrm{COC}^{*} \mathrm{OOC} .+\mathrm{CH}_{3} \mathrm{OH}$

$14 \mathrm{COC}^{*} \mathrm{OOC}+\mathrm{C}_{2} \mathrm{H}_{3}=\mathrm{COC}^{*} \mathrm{OOC} .+\mathrm{C}_{2} \mathrm{H}_{4}$

$15 \mathrm{COC}^{*} \mathrm{OOC}+\mathrm{C}_{2} \mathrm{H}_{5}=\mathrm{COC}^{*} \mathrm{OOC} .+\mathrm{C}_{2} \mathrm{H}_{6}$

$16 \mathrm{COC}^{*} \mathrm{OOC}+\mathrm{H}=>\mathrm{COC}{ }^{*} \mathrm{OOH}+\mathrm{CH}_{3}$

$17 \mathrm{COC}^{*} \mathrm{OOC}+\mathrm{H}=>\mathrm{CH}_{3} \mathrm{OCHO}+\mathrm{CH}_{3} \mathrm{O}$

$18 \mathrm{COC}^{*} \mathrm{OOH}+\mathrm{OH}=\mathrm{C} \cdot \mathrm{OC}^{*} \mathrm{OOH}+\mathrm{H}_{2} \mathrm{O}$

$19 \mathrm{COC}^{*} \mathrm{OOH}+\mathrm{H}=\mathrm{C} . \mathrm{OC}^{*} \mathrm{OOH}+\mathrm{H}_{2}$

$20 \mathrm{COC} * \mathrm{OOH}+\mathrm{CH}_{3}=\mathrm{C} . \mathrm{OC}^{*} \mathrm{OOH}+\mathrm{CH}_{4}$

$21 \mathrm{COC}^{*} \mathrm{OOH}+\mathrm{O}=\mathrm{C} . \mathrm{OC}^{*} \mathrm{OOH}+\mathrm{OH}$

$22 \mathrm{C} . \mathrm{OC}^{*} \mathrm{OOH}=>\mathrm{CH}_{2} \mathrm{O}+\mathrm{CO}+\mathrm{OH}$

$23 \mathrm{CH}_{3} \mathrm{OC} . \mathrm{O}+\mathrm{CH}_{2} \mathrm{O}=\mathrm{COC}^{*} \mathrm{OOC}$.

$24 \mathrm{CH}_{3} \mathrm{O}+\mathrm{CO}_{2}=\mathrm{COC} * \mathrm{OO}$.
A $n \quad$ Ea Reference

$2.39 \mathrm{E}+12 \quad 0.19 \quad 6.98 \mathrm{E}+04 \quad \mathrm{a}$

$4.20 \mathrm{E}+13 \quad 0.00 \quad 5.35 \mathrm{E}+04 \quad b$

$5.00 \mathrm{E}+13 \quad 0.00 \quad 0.00 \mathrm{E}+00 \quad \mathrm{C}$

$3.00 E+13 \quad 0.00 \quad 0.00 E+00 \quad d$

$3.00 E+13 \quad 0.00 \quad 0.00 E+00 \quad d$

$\begin{array}{lll}7.02 \mathrm{E}+07 & 1.61 & -3.50 \mathrm{E}+01 \quad \mathrm{e}\end{array}$

$9.75 E+05 \quad 2.40 \quad 4.47 E+03 \quad f$

$\begin{array}{lll}4.06 E+04 & 2.26 & 7.29 E+03 \quad f\end{array}$

$7.16 E+04 \quad 2.71 \quad 2.11 E+03 \quad f$

$8.40 \mathrm{E}+12 \quad 0.00 \quad 1.77 \mathrm{E}+04 \quad \mathrm{~g}$

H 8.40E+12 $0.00 \quad 1.77 \mathrm{E}+04 \quad \mathrm{~g}$

$3.16 \mathrm{E}+11 \quad 0.00 \quad 7.00 \mathrm{E}+03 \quad h$

$1.00 \mathrm{E}+12 \quad 0.00 \quad 1.80 \mathrm{E}+04 \quad \mathrm{~h}$

$1.00 \mathrm{E}+11 \quad 0.00 \quad 1.34 \mathrm{E}+04 \quad \mathrm{~h}$

$3.79 \mathrm{E}+16 \quad-1.39 \quad 5.40 \mathrm{E}+03 \quad$ I

4.76E+09 $1.02 \quad 5.18 \mathrm{E}+03 \quad j$

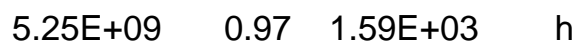

$9.40 \mathrm{E}+04 \quad 2.75 \quad 6.28 \mathrm{E}+03 \quad i$

4.52E-01 $3.65 \quad 7.15 E+03 \quad k$

$9.65 \mathrm{E}+04 \quad 2.68 \quad 3.72 \mathrm{E}+03 \quad k$

$6.10 \mathrm{E}+21 \quad-2.40 \quad 3.25 \mathrm{E}+04 \quad$ ।

$\begin{array}{lll}1.06 \mathrm{E}+11 & 0.00 & 7.35 \mathrm{E}+03 \quad \mathrm{~m}\end{array}$

$1.00 \mathrm{E}+11 \quad 0.00 \quad 9.20 \mathrm{E}+03 \quad \mathrm{n}$ 

$25 \mathrm{CH}_{3}+\mathrm{CO}_{2}=\mathrm{CH}_{3} \mathrm{OC} . \mathrm{O}$
4.76E+07 $1.54 \quad 3.47 \mathrm{E}+04 \quad 0$
$26 \mathrm{CH}_{3} \mathrm{O}+\mathrm{CO}=\mathrm{CH}_{3} \mathrm{OC} . \mathrm{O}$
$1.55 \mathrm{E}+06 \quad 2.02 \quad 5.73 \mathrm{E}+03 \quad 0$

${ }^{\mathrm{a}}$ This paper. Ea from $\mathrm{CBS}-\mathrm{Q}, \mathrm{AT}^{\mathrm{n}}$ from $\mathrm{MTBE}=>\mathrm{IC}_{4} \mathrm{H}_{8}+\mathrm{CH}_{3} \mathrm{OH}$ [18], times $1 / 9$ for degeneracy because MTBE has 9 possible transition states and DMC has one.

${ }^{\mathrm{b}} \mathrm{A}=7.0 \times 10^{12}$ per $\mathrm{H}$-atom, Ea=internal energy change of reaction. Reaction rate constant rule from [19].

${ }^{\mathrm{c}}$ Analogy with $\mathrm{H}+$ primary alkyl radical reaction rate rule from [19].

${ }^{d}$ Assumed the same rate as high pressure rate for $\mathrm{CH}_{3} \mathrm{O}+\mathrm{CH}_{3}=>\mathrm{CH}_{3} \mathrm{OCH}_{3}$ [14].

${ }^{\mathrm{e}}$ Assumed rate rule for abstraction of secondary $\mathrm{H}$-atom by $\mathrm{OH}$ from [20].

${ }^{\mathrm{f}}$ Assumed rate rule for abstraction of secondary H-atom from LLNL mechanism nc7_38.

${ }^{\mathrm{g}}$ Assumed rate rule for abstraction of secondary H-atom from [19].

${ }^{\mathrm{h}}$ Assumed rate rule for abstraction of primary $\mathrm{H}$ atom from [20].

${ }^{\mathrm{i}}$ Analogy with $\mathrm{CH}_{2} \mathrm{O}+\mathrm{H}=\mathrm{CH}_{2} \mathrm{OH}$ from [21].

${ }^{\mathrm{J}}$ Analogy with $\mathrm{CH}_{2} \mathrm{O}+\mathrm{H}=\mathrm{CH}_{3} \mathrm{O}$, reverse rate from [22].

${ }^{\mathrm{k}}$ Assumed rate rule for abstraction of primary H-atom from LLNL mechanism nc7_38.

${ }^{1}$ Analogy with $\mathrm{CH}_{2} \mathrm{O}+\mathrm{HCO}=\mathrm{CH}_{2} \mathrm{OCHO}$

${ }^{m}$ Analogy with $\mathrm{CH}_{3} \mathrm{CO}+\mathrm{C}_{2} \mathrm{H}_{4}=\mathrm{CH}_{2} \mathrm{CH}_{2} \mathrm{COCH}_{3}$, from [19].

${ }^{\mathrm{n}}$ Reaction rate rule from [14].

${ }^{\mathrm{o}}$ This paper.

Note: “*” means double bond, carbons are assumed to be saturated except where there is a radical site denoted by “.”. "=>” denotes forward direction only. 
Table 4: Reactions with the highest first-order sensitivity coefficients with respect to the rate constants for each observed species. The sensitivity coefficients were computed point of maximum concentration, except for the fuel which was computed at the point of $50 \%$ consumed. (Radical sites are denoted by “.”)

\begin{tabular}{|c|c|c|c|c|c|c|c|c|}
\hline & $\mathrm{CH}_{4}$ & $\mathbf{C}_{2} \mathbf{H}_{2}$ & $\mathbf{C}_{2} \mathbf{H}_{4}$ & $\mathbf{C}_{2} \mathbf{H}_{6}$ & $\mathrm{CH}_{2} \mathrm{O}$ & $\mathrm{CO}$ & $\mathrm{CO}_{2}$ & DMC \\
\hline $\mathrm{CH} 3+\mathrm{H}(+\mathrm{M})=\mathrm{CH} 4(+\mathrm{M})$ & 0.10 & -0.35 & -0.22 & 0.13 & & -0.08 & -0.02 & 0.031 \\
\hline $\mathrm{CH} 4+\mathrm{H}=\mathrm{CH} 3+\mathrm{H} 2$ & 0.07 & & & -0.06 & 0.06 & & & \\
\hline $\mathrm{CO}+\mathrm{OH}=\mathrm{CO} 2+\mathrm{H}$ & & & & & & -0.08 & 0.03 & \\
\hline $\mathrm{H}+\mathrm{O} 2=\mathrm{O}+\mathrm{OH}$ & & 0.16 & 0.09 & & & & 0.03 & -0.019 \\
\hline $\mathrm{HCO}+\mathrm{M}=\mathrm{H}+\mathrm{CO}+\mathrm{M}$ & & 0.27 & 0.20 & 0.14 & & 0.07 & 0.02 & -0.029 \\
\hline $\mathrm{C} 2 \mathrm{H} 6+\mathrm{H}=\mathrm{C} 2 \mathrm{H} 5+\mathrm{H} 2$ & & & 0.19 & & & & & \\
\hline $\mathrm{CH} 3+\mathrm{CH} 3(+\mathrm{M})=\mathrm{C} 2 \mathrm{H} 6(+\mathrm{M})$ & -0.38 & 0.32 & 0.28 & & -0.06 & & & \\
\hline $\mathrm{H} 2 \mathrm{O}+\mathrm{M}=\mathrm{H}+\mathrm{OH}+\mathrm{M}$ & & & & & & & -0.01 & 0.011 \\
\hline $\mathrm{H}+\mathrm{O} 2(+\mathrm{M})=\mathrm{HO} 2(+\mathrm{M})$ & & & -0.09 & -0.05 & 0.02 & -0.20 & -0.02 & 0.025 \\
\hline $\mathrm{CH} 2 \mathrm{O}+\mathrm{OH}=\mathrm{HCO}+\mathrm{H} 2 \mathrm{O}$ & & & & & -0.04 & & & \\
\hline $\mathrm{CH} 2 \mathrm{O}+\mathrm{H}=\mathrm{HCO}+\mathrm{H} 2$ & -0.06 & & & & -0.47 & & & \\
\hline $\mathrm{CH} 2 \mathrm{O}+\mathrm{CH} 3=\mathrm{HCO}+\mathrm{CH} 4$ & 0.12 & & & -0.05 & & & & \\
\hline $\mathrm{HCO}+\mathrm{CH} 3=\mathrm{CH} 4+\mathrm{CO}$ & 0.05 & -0.14 & -0.11 & -0.08 & & & -0.01 & 0.012 \\
\hline $\mathrm{C} 2 \mathrm{H} 2+\mathrm{H}(+\mathrm{M})=\mathrm{C} 2 \mathrm{H} 3(+\mathrm{M})$ & & 0.18 & & & & & & \\
\hline $\mathrm{C} 2 \mathrm{H} 2+\mathrm{O}=\mathrm{HCCO}+\mathrm{H}$ & & -0.23 & & & & & & \\
\hline $\mathrm{CH} 3+\mathrm{CO} 2=\mathrm{CH} 3 \mathrm{OCO}$ & 0.05 & & 0.09 & 0.11 & -0.12 & -0.16 & -0.01 & 0.037 \\
\hline $\mathrm{CH} 3 \mathrm{O}+\mathrm{CO}=\mathrm{CH} 30 \mathrm{CO}$ & 0.05 & & -0.08 & -0.11 & 0.12 & 0.15 & 0.01 & -0.036 \\
\hline $\mathrm{COC} \star \mathrm{OOC}+\mathrm{H}=\mathrm{COC} \star \mathrm{OOC} .+\mathrm{H} 2$ & 0.09 & & 0.05 & 0.20 & 0.22 & & 0.01 & 0.006 \\
\hline $\begin{aligned} & \mathrm{COC} \star \mathrm{OOC}+\mathrm{CH} 3 \\
= & \mathrm{COC} \star \mathrm{OOC} \cdot+\mathrm{CH} 4\end{aligned}$ & 0.11 & & & & & & & -0.006 \\
\hline $\begin{array}{c}\mathrm{COC} * \mathrm{OOC}+\mathrm{H} \\
=>\mathrm{CH} 3 \mathrm{OCHO}+\mathrm{CH} 3 \mathrm{O}\end{array}$ & & & & & 0.07 & 0.06 & & -0.019 \\
\hline
\end{tabular}




\section{Figure Captions}

Figure 1: Predicted (curves) and measured (symbols) mole fraction profiles of the major species and temperature in the DMC opposed-flow diffusion flame.

Figure 2: Predicted (curves) and measured (symbols) mole fraction profiles of the minor species in the DMC opposed-flow diffusion flame.

Figure 3: Predicted (curves) and measured (symbols) mole fraction profile of formaldehyde in the DMC opposed-flow diffusion flame.

Figure 4. Main reaction paths for DMC in the opposed-flow diffusion flame (numbers refer to reactions in Table 3; percentages refer to a reaction pathway's share of a specie's consumption). 